\title{
Brown Flaxseed Prevents DNA Damage Induced by 1,2- Dimethylhydrazine in a Pre-Clinical Model
}

\author{
Maria Tereza Pamplona-Silva ${ }^{1}$, Walter Vinicius Morandi $^{1}$, Luana Bernardi ${ }^{2}$, Bethânia \\ Borges Tura², Diego Duarte Marques de Oliveira², Andreia Conceição Milan Brochado \\ Antoniolli-Silva ${ }^{2}$, Mariana de Oliveira Mauro ${ }^{3}$, Rodrigo Oliveira ${ }^{2 *}$ \\ ${ }^{1}$ Centro Universitario Filadelfia, Londrina, Paraná, Brasil. ${ }^{2}$ Universidade Federal de Mato Grosso do Sul, Campo \\ Grande, Mato Grosso do Sul, Brasil. ${ }^{3}$ Universidade Estadual de Mato Grosso do Sul - Campo Grande, Mato Grosso \\ do Sul, Brasil
}

\begin{abstract}
The study evaluated the effects of brown flaxseed supplementation in natura on the prevention of DNA damage induced by 1,2-dimethylhydrazine (DMH) in vivo. The experimental groups were Negative and Positive Controls and the protocols of Pre-treatment, Simultaneous, Post-treatment, Pre+continuous in relation to the supplementation of brown flaxseed and administration with carcinogenic compound. The results showed that brown flaxseed supplementation does not cause genomic and genetic damage. In addition, brown flaxseed showed a chemopreventive food that reduced the damages assessed by the comet assay up to 94.07x and the damages assessed by the micronucleus assay up to 91.88x. Brown flaxseed supplementation also increased the frequency of monocytes and lymphocytes indicating immunological improvements. Thus, brown flaxseed supplementation is considered safe and reduces the frequency of DNA damage that can lead to tumors. Therefore, if these events are confirmed in humans, flaxseed will have reinforced its indication as a functional chemopreventive food in the prevention of cancer.
\end{abstract}

Keywords: flaxseed; antigenotoxicity; chemoprevention; mice

\footnotetext{
* Author for correspondence: rodrigo.oliveira@ufms.br.
} 


\section{INTRODUCTION}

Cancer is a disease of high and increasing prevalence in the world and is characterized as one of the main causes of morbidity and mortality, besides assigning low quality of life ${ }^{1}$. According to the World Health Organization, cancer was responsible for 8.8 million deaths in $2015^{2}$. In addition, the National Cancer Institute (NCI) estimates 600,000 new cases of cancer each year in Brazil, in the biennium 2018-2019 ${ }^{3}$. Faced with this public health issue, the search for functional and chemopreventive foods that may prevent the development of this disease ${ }^{4}$ is becoming more urgent. In addition, in its recommendations for accelerating the pace of cancer research twofold, the Beau Biden Cancer Moonshot Blue Ribbon Panel cited prevention as key to fulfilling this goal ${ }^{5}$.

Flaxseed is considered a functional product because it is a source of several nutritional components ${ }^{6}$. The consumption of flaxseed is related to health benefits, such as the prevention or improvement of parameters associated with cardiovascular diseases, hepatic diseases and cancer prevention ${ }^{7,8}$. The anticancer function of flaxseed is due to the presence of lignins that have antioxidant action that eliminates free radicals ${ }^{9}$; flaxseed also has a high concentration of oil, rich in polyunsaturated fatty acids and is capable of reducing the viability of cancer cells ${ }^{10}$. In addition, fibers present in flaxseed have a hypocholesterolemic, blood pressure-controlling and modulating glycemic response ${ }^{11,12}$.

Considering the above, the present study evaluated the effects of supplementation of brown flaxseed "in natura" on prevention of DNA damage induced by 1,2dimethylhydrazine in a preclinical model.

\section{MATERIALS AND METHODS}

\section{Chemical Agents}

For the induction of intestinal lesions and DNA damage, 1,2-dimethylhydrazine (DMH; Sigma ${ }^{\circledR}$, CAS No. 306-37-6) at a concentration of $20 \mathrm{mg} / \mathrm{kg}$ body weight (b.w.) was used intraperitoneally (i.p.) diluted in EDTA solution $(0.37 \mathrm{mg} / \mathrm{ml})$. Four doses of DMH were administered: two doses per week for two weeks $4,13,14,15$.

\section{Functional Food}

Brown flaxseed was purchased from Macrovida Comércio de Produtos Naturais e Integrais Ltda ${ }^{\circledR}$. The supplementation occurred at the concentration of $10 \%$ of ground brown flaxseed added to the basal diet (Nuvilab®).

\section{Animals and Experimental Design}

Seven experimental groups were used with 7 animals in each group, being these mice of the Swiss variety (Mus musculus), males and of reproductive age, from the Center of Studies in Nutrition and Toxicological Genetics - CENUGEN allocated in the University Center Filadélfia - UniFil, Londrina, PR. The experiment was conducted according to the guidelines of the Universal Declaration of Animal Rights and with the approval of the Ethics Committee on Animal Use, Universidade Federal do Mato Grosso do Sul (Protocol No 767/2016).

The animals were treated for 4 weeks and 72 hours, according to the protocol suggested by Ishii et al. ${ }^{13}$ : Control group: the animals received only commercial feed for 4 weeks, and the EDTA solution $\left(0.1 \mathrm{ml} / 10 \mathrm{~g}\right.$ b.w., i.p.) was administered at the $3^{\text {rd }}$ and $4^{\text {th }}$ weeks twice a week. The peripheral blood collection occurred in T1, T2 and T3, being these 24, 48 and 72 hours after the last administration of the vehicle (i.p.) in the case of the 
micronucleus and for the differential count of blood cells and for the comet assay the collections were performed only on T1. DMH group: the animals were treated and submitted to blood collection in the same way as the control group. However, EDTA was replaced by DMH (20mg / kg b.w., i.p.). Brown flaxseed group: animals were treated and blood was collected in the same manner as described for the control group. However, the commercial feed was replaced by commercial feed supplemented with $10 \%$ flaxseed. Pre-treatment group: the animals received during the first two weeks the supplementation with the commercial feed supplemented with brown flaxseed (10\%). After the end of this period, treatment with DMH, 4 doses, two doses per week ( $3^{\text {rd }}$ and $4^{\text {th }}$ weeks) and the $3^{\text {rd }}$ week until the end of the experiment the animals were fed commercial feed. Peripheral blood was collected in the same manner as described for the control group. Simultaneous group: Commercial feed was offered during the first two weeks of experimentation. In the following two weeks $\left(3^{\text {rd }}\right.$ and $4^{\text {th }}$ weeks $)$ the animals received the 4 doses of DMH. At this time the animals were fed commercial feed supplemented with brown flaxseed (10\%). After the DMH administration period, the feed supplemented with brown flaxseed was replaced by commercial feed. Peripheral blood was collected in the same manner as described for the control group. Post-treatment: in the four experimental weeks the animals received commercial feed. In the $3^{\text {rd }}$ and $4^{\text {th }}$ weeks they received the 4 doses of DMH. Then, in the last 72 experimental hours, the animals were treated with the feed supplemented with brown flaxseed. Peripheral blood was collected in the same manner as described for the control group. Pre+continuous: commercial feed supplemented with brown flaxseed (10\%) was administered throughout the experimental period (4 weeks and 72 hours), in the $3^{\text {rd }}$ and $4^{\text {th }}$ weeks the animals were treated with DMH. Peripheral blood was collected in the same manner as described for the control group.

\section{Comet Assay}

The comet assay was performed according to Oliveira et al. ${ }^{16} .100$ cells were analyzed flaxseed per treatment ${ }^{17,18}$. The total score was calculated by summing the values resulting from the multiplication of the total cells observed in each lesion class $(0,1,2$ or 3 ) by the class value ${ }^{16,17}$. Statistical analysis was performed by ANOVA / Tukey (p $<0.05)$.

\section{Micronucleus Test in Peripheral Blood}

The protocol of Hayashi et al. ${ }^{19}$ was used with modifications proposed by Oliveira et al. ${ }^{20,21} .2000$ cells / animal were analyzed and the statistic was performed using the ANOVA / Tukey test $(\mathrm{p}<0.05)$.

\section{Differential Cells}

The preparation of the slides for analysis followed the protocol already described ${ }^{22}$. We analyzed 100 cells per animal and differentiated into lymphocytes, neutrophils, monocytes, eosinophils and basophils. Statistical analysis was performed by ANOVA / Tukey $(\mathrm{p}<0.05)$.

\section{Percentage of Harm Reduction}

The percentage of damage reduction of DMH agent by brown flaxseed was calculated using an already standardized method, with the final result multiplied by 100 4,13,15,23.

\section{RESULTS AND DISCUSSION}

The initial weight and final weight did not differ between the different experimental groups. In the weight increasing, an increase $(\mathrm{p}<0.05)$ was observed in the Pre+continuous group in relation to the other groups (Table 1). When analyzing the 
absolute and relative weight of the organs no significant change ( $p>0.05$ ) was observed for lung, liver and kidneys. However, the absolute heart weight was increased in DMH, Brown flaxseed and Pre+continuous groups. When evaluating the relative weight, it was verified that only the heart weight of the Brown flaxseed group remained altered (Table 2). This data was therefore analyzed in the general context of the study, it does not indicate possible the effects of cardiotoxics for the consumption of flaxseed. When we analyze the trend of weight gain in the Brown flaxseed group and the significant weight gain in the Pre+continuous group, which are those groups that have received the supplementation of brown flaxseed for a longer time, this suggests the beneficial effect that the constituents of this group may exert on target organs of DMH, once it is metabolized in hepatic level.

Flaxseed emerges as a potential functional food because of its nutritional content, rich in biologically active components, and by the growing consumer interest in products that provide health benefits ${ }^{6}$. Flaxseed consumption has occurred since ancient times and although its edible products include the most diverse forms (flaxseed, ground flour and oil extracted or mucilage) ${ }^{6}$. We are pioneering the use of fresh flaxseed, without any kind of processing, in the prevention of DNA damage.

The higher weight gain among those who consumed the flaxseed for longer (trend for the Brown flaxseed and a significant increase for the Pre+continuous group) reflects both the higher caloric intake, made possible by the constituents of the seed, for example, by the high lipid content ${ }^{24}$, the benefits it provides to the weakened organism. Among the bioactive compounds, they are also lignins, with anticarcinogenic, antiestrogenic, antiangiogenic and antioxidant properties ${ }^{25}$; $\alpha$-linolenic acid, with antioxidant, anti-inflammatory ${ }^{26}$ and anticarcinogenic activity ${ }^{27}$; and the food fibers turns, with anticarcinogenic capacity, that act through the adsorption of mutagenic and / or carcinogenic agents ${ }^{28}$. Thus, a nutritional demonstration of the flaxseed for health recovery and, consequently, promoted healthy increasing weight.

Table 1. Mean values \pm standard error of mean initial weight, final weight and weight gain of animals during the experimental period.

\begin{tabular}{llll}
\hline Experimental Groups & Inicial weight $(\mathbf{g})$ & Final weight $(\mathbf{g})$ & Increasing weight $(\mathbf{g})$ \\
\hline Control & $43.42 \pm 3.21^{\mathrm{a}}$ & $44.00 \pm 2.31^{\mathrm{a}}$ & $0.57 \pm 1.51^{\mathrm{a}}$ \\
DMH & $42.85 \pm 1.95^{\mathrm{a}}$ & $45.42 \pm 2.99^{\mathrm{a}}$ & $2.57 \pm 1.90^{\mathrm{a}}$ \\
Flaxseed & $42.00 \pm 3.05^{\mathrm{a}}$ & $48.00 \pm 3.05^{\mathrm{a}}$ & $6.00 \pm 1.15^{\mathrm{a} . \mathrm{b}}$ \\
Pre-treatment & $43.14 \pm 4.59^{\mathrm{a}}$ & $45.71 \pm 4.82^{\mathrm{a}}$ & $2.57 \pm 2.99^{\mathrm{a}}$ \\
Simultaneous & $41.71 \pm 4.53^{\mathrm{a}}$ & $45.14 \pm 6.81^{\mathrm{a}}$ & $3.42 \pm 4.72^{\mathrm{a}}$ \\
Post-treatment & $40.00 \pm 4.89^{\mathrm{a}}$ & $45.42 \pm 2.76^{\mathrm{a}}$ & $5.42 \pm 4.86^{\mathrm{a}}$ \\
Pre+continuous & $42.28 \pm 2.13^{\mathrm{a}}$ & $48.14 \pm 2.79^{\mathrm{a}}$ & $6.85 \pm 2.26^{\mathrm{b}}$ \\
\hline
\end{tabular}

Legend: g - grams; Control - EDTA 0.1mL / 10g, b.w. (body weight); DMH -1,2-Dimethylhydrazine, 20mg / kg, b.w. during 2 weeks (positive control); Flaxseed - Linum usitatissimum - 10\% c.f. (commercial feed) for 4 weeks +72 hours; Pre-treatment Flaxseed $10 \%$ c.f.. during the first 2 weeks + DMH $20 \mathrm{mg} / \mathrm{kg}$ b.w. for 2 weeks; Simultaneous Treatment - Flaxseed $10 \%$ c.f. + DMH 20mg / kg, b.w. for 2 weeks; Post Treatment - DMH 20mg / kg, b.w. for 2 weeks + flaxseed $10 \%$ c.f. for 72 hours thereafter; Pre+continuous treatment - flaxseed $10 \%$ c.f. for 4 weeks +72 hours + DMH 20mg / kg, b.w. for 2 weeks. Different letters indicate statistically significant differences ( $\mathrm{p}<0.05$; ANOVA / Tukey). 
Table 2. Mean values \pm standard error of mean absolute and relative body weight of animals after the experiment period

\begin{tabular}{|c|c|c|c|c|c|c|c|c|}
\hline \multirow{2}{*}{$\begin{array}{l}\text { Experimental } \\
\text { Groups }\end{array}$} & \multicolumn{4}{|l|}{ Total weight (g) } & \multicolumn{4}{|l|}{ Relative Weight (g) } \\
\hline & Heart & Lung & Liver & Kidneys & Heart & Lung & Liver & Kidneys \\
\hline Control & $0.2218 \pm 0.013^{\mathrm{a}}$ & $0.2871 \pm 0.057^{\mathrm{a}}$ & $2.5215 \pm 0.167^{a}$ & $0.6314 \pm 0.080^{\mathrm{a}}$ & $0.0050 \pm 0.0003^{\mathrm{a}}$ & $0.0065 \pm 0.001^{\mathrm{a}}$ & $0.0574 \pm 0.005^{\mathrm{a}}$ & $0.0144 \pm 0.002^{\mathrm{a}}$ \\
\hline DMH & $0.2912 \pm 0.0405^{\mathrm{b}}$ & $0.2619 \pm 0.031^{\mathrm{a}}$ & $2.7190 \pm 0.359^{\mathrm{a}}$ & $0.7935 \pm 0.126^{\mathrm{a}}$ & $0.0064 \pm 0.0009^{a . b}$ & $0.0057 \pm 0.0007^{\mathrm{a}}$ & $0.0600 \pm 0.009^{\mathrm{a}}$ & $0.0176 \pm 0.003^{\mathrm{a}}$ \\
\hline Flaxseed & $0.3295 \pm 0.040^{c}$ & $0.2907 \pm 0.046^{\mathrm{a}}$ & $2.6683 \pm 0.381^{\mathrm{a}}$ & $0.7344 \pm 0.075^{\mathrm{a}}$ & $0.0069 \pm 0.001^{\mathrm{b}}$ & $0.0060 \pm 0.0008^{a}$ & $0.0558 \pm 0.009^{\mathrm{a}}$ & $0.0153 \pm 0.018^{\mathrm{a}}$ \\
\hline Pre-treatment & $0.2279 \pm 0.041^{a . b}$ & $0.2661 \pm 0.039^{\mathrm{a}}$ & $2.3000 \pm 0.416^{\mathrm{a}}$ & $0.7493 \pm 0.127^{\mathrm{a}}$ & $0.0050 \pm 0.0009^{a}$ & $0.0058 \pm 0.0008^{a}$ & $0.0504 \pm 0.008^{\mathrm{a}}$ & $0.0163 \pm 0.002^{\mathrm{a}}$ \\
\hline Simultaneous & $0.2660 \pm 0.052^{\text {a.b.c }}$ & $0.2575 \pm 0.036^{\mathrm{a}}$ & $2.3243 \pm 0.376^{\mathrm{a}}$ & $0.6859 \pm 0.118^{\mathrm{a}}$ & $0.0059 \pm 0.001^{\mathrm{a}}$ & $0.0057 \pm 0.0009^{a}$ & $0.0534 \pm 0.011^{\mathrm{a}}$ & $0.0154 \pm 0.003^{\mathrm{a}}$ \\
\hline Post-treatment & $0.2732 \pm 0.047^{\text {a.b.c }}$ & $0.2701 \pm 0.040^{\mathrm{a}}$ & $2.6525 \pm 0.392^{\mathrm{a}}$ & $0.7912 \pm 0.089^{\mathrm{a}}$ & $0.0060 \pm 0.001^{\mathrm{a}}$ & $0.0059 \pm 0.001^{\mathrm{a}}$ & $0.0583 \pm 0.007^{\mathrm{a}}$ & $0.0175 \pm 0.003^{\mathrm{a}}$ \\
\hline Pre+continuous & $0.3242 \pm 0.086^{\mathrm{d}}$ & $0.2934 \pm 0.068^{\mathrm{a}}$ & $2.5420 \pm 0.432^{\mathrm{a}}$ & $0.7457 \pm 0.126^{\mathrm{a}}$ & $0.0065 \pm 0.001^{\mathrm{a}}$ & $0.0059 \pm 0.001^{\mathrm{a}}$ & $0.0055 \pm 0.006^{\mathrm{a}}$ & $0.0151 \pm 0.002^{\mathrm{a}}$ \\
\hline
\end{tabular}
Legend: g - grams; Control - EDTA 0.1mL / 10g, b.w. (body weight); DMH -1,2-Dimethylhydrazine, 20mg / kg, b.w. during 2 weeks (positive control); Flaxseed - Linum usitatissimum-
$10 \%$ c. $10 \%$ c.f + DMH $20 \mathrm{mg} / \mathrm{kg}$, b.w. for 2 weeks; Pours; Pre-treatment - Flaxsea $/ \mathrm{kg}$ b.w. for 2 weeks + flaxseed $10 \%$ c f. for 72 hours thereafter; Pre+continuous treatment - flaxseed $10 \%$ c.f. for 4 weeks +72 hours + DMH 20mg / kg, b.w. for 2 weeks. Different letters indicate statistically significant differences (p <0.05; ANOVA / Tukey) 
The comet assay demonstrated that DMH is capable of inducing increased DNA damage in the order of 49.18x. This fact validates it as a genotoxic positive control, toxic to the cellular genome, even though it is a weak initiator and a strong promoter ${ }^{29,30}$. The flaxseed when supplemented did not cause genotoxic damage, which suggests safety of its use in supplementation. However, when associated with DMH, regardless of supplementation protocol, flaxseed presented high chemoprevention, which is demonstrated by satisfactory percentages of harm reduction (Table 3). However, these percentages cannot allow to establishing correlation between the time of supplementation and the levels of chemoprevention. This fact is also described for other functional foods such as inulin ${ }^{4}$, glutamine ${ }^{31}$ and the commercial product Activia ${ }^{\circledR 2}{ }^{32}$. The score values indicated that DMH treatment alone causes the highest level of DNA damage and that brown flaxseed supplementation is able to significantly reduce these damages, thus reinforcing its character as a functional chemo-preventive food. Except for the Post-treatment group, which is also chemopreventive, the other antigenotoxicity protocols presented a score similar to that of the negative control. These facts demonstrate how good flaxseed consumption is for the prevention of DNA damage that may correlate with the development of tumors ${ }^{33,34}$. 
Table 3. Mean values \pm standard deviations of the mean of the lesioned cell frequency, distribution between the damage and score classes for the genotoxicity and antigenotoxicity tests performed by the comet assay in peripheral blood of Swiss male mice feed commercial feed or commercial feed supplemented with $10 \%$ flaxseed.

\begin{tabular}{|c|c|c|c|c|c|c|c|}
\hline \multirow{2}{*}{$\begin{array}{l}\text { Experimental } \\
\text { Groups }\end{array}$} & \multirow{2}{*}{$\begin{array}{l}\text { Injured } \\
\text { Cells }\end{array}$} & \multicolumn{4}{|c|}{ Classes of Damage } & \multicolumn{2}{|l|}{ Score $\quad \%$ RD } \\
\hline & & $\mathbf{0}$ & 1 & 2 & 3 & & \\
\hline Control & $2.00 \pm 1.73^{\mathrm{a}}$ & $98.00 \pm 1.73^{\mathrm{a}}$ & $2.00 \pm 1.73^{\mathrm{a}}$ & $0.00 \pm 0.00^{\mathrm{a}}$ & $0.00 \pm 0.00^{\mathrm{a}}$ & $2.00 \pm 1.73^{\mathrm{a}}$ & - \\
\hline DMH & $98.36 \pm 0.43^{\mathrm{c}}$ & $1.54 \pm 0.45^{\mathrm{b}}$ & $5.64 \pm 2.34^{\mathrm{c}}$ & $14.90 \pm 1.55^{\mathrm{c}}$ & $77.82 \pm 3.49^{\mathrm{b}}$ & $268.90 \pm 6.35^{\mathrm{c}}$ & - \\
\hline \multicolumn{8}{|l|}{ Genotoxicity } \\
\hline Flaxseed & $0.42 \pm 0.78^{\mathrm{a}}$ & $99.57 \pm 0.78^{\mathrm{a}}$ & $0.42 \pm 0.78^{\mathrm{a}}$ & $0.00 \pm 0.00^{\mathrm{a}}$ & $0.00 \pm 0.00^{\mathrm{a}}$ & $0.42 \pm 0.78^{\mathrm{a}}$ & - \\
\hline \multicolumn{8}{|l|}{ Antigenotoxicity } \\
\hline Pre-treatment & $7.71 \pm 1.89^{\text {a.b }}$ & $92.28 \pm 1.89^{\text {a.c }}$ & $7.14 \pm 1.67^{\mathrm{b}}$ & $0.57 \pm 0.78^{\mathrm{a} . \mathrm{b}}$ & $0.00 \pm 0.00^{\mathrm{a}}$ & $8.28 \pm 2.36^{\mathrm{a}}$ & 94.07 \\
\hline Simultaneous & $13.14 \pm 3.97^{\mathrm{b}}$ & $86.85 \pm 3.97^{\mathrm{c}}$ & $11.14 \pm 3.18^{\mathrm{d}}$ & $1.42 \pm 1.39^{\text {a.b }}$ & $0.57 \pm 0.78^{\mathrm{a}}$ & $15.71 \pm 5.73^{\mathrm{a} . \mathrm{b}}$ & 88.43 \\
\hline Post-treatment & $15.57 \pm 3.59^{\mathrm{b}}$ & $84.42 \pm 3.59^{\mathrm{c}}$ & $6.00 \pm 2.70^{\mathrm{b}}$ & $4.85 \pm 2.47^{\mathrm{b}}$ & $4.71 \pm 2.56^{\mathrm{a}}$ & $29.85 \pm 10.14^{\mathrm{b}}$ & 85.91 \\
\hline Pre+continuous & $7.71 \pm 2.28^{\mathrm{a} . \mathrm{b}}$ & $92.28 \pm 2.28^{\mathrm{a} . \mathrm{c}}$ & $3.57 \pm 1.27^{\mathrm{a} . \mathrm{b}}$ & $2.85 \pm 1.21^{\mathrm{b}}$ & $1.28 \pm 1.38^{\mathrm{a}}$ & $13.14 \pm 5.21^{\mathrm{a} . \mathrm{b}}$ & 94.07 \\
\hline
\end{tabular}

Legend: \% DR - Percent reduction of DNA damage. Control - EDTA 0.1mL / 10g, b.w. (body weight); DMH -1,2-Dimethylhydrazine, 20mg / kg, b.w. during 2 weeks (positive control); Flaxseed - Linum usitatissimum - 10\% c.f. (commercial feed) for 4 weeks +72 hours; Pre-treatment - Flaxseed 10\% c.f. during the first 2 weeks + DMH $20 \mathrm{mg} / \mathrm{kg}$ b.w. for 2 weeks; Simultaneous Treatment - Flaxseed 10\% c.f. + DMH 20mg / kg, b.w. for 2 weeks; Post-Treatment - DMH 20mg / kg, b.w. for 2 weeks + flaxseed $10 \%$ c.f. for 72 hours thereafter; Pre + Continuous Treatment - flaxseed $10 \%$ c.f.. for 4 weeks +72 hours + DMH $20 \mathrm{mg} / \mathrm{kg}$, b.w. for 2 weeks. Different letters indicate statistically significant differences (p <0.05; ANOVA / Tukey). 
The micronucleus assay demonstrated that DMH increases the frequency of this biomarker by $35.05 \mathrm{x}, 27.76 \mathrm{x}$ and $19.91 \mathrm{x}$ at 24,48 and $72 \mathrm{~h}$ times (Table 4 ). The results confirm the genotoxic effect at chromosome level. This increase in chromosomal instability is directly related to the development of tumors ${ }^{35}$, especially in the colorectal cancer, since this drug has tropism in this region and is a good inducer of premalignant lesions in this region ${ }^{36}$ to cause, in addition to DNA damage and genomic and genetic instability, an inflammatory process leading to the development of aberrant crypt outbreaks ${ }^{37}$.

Brown flaxseed supplementation caused a statistically significant increase in micronucleus frequency in 48 and 72 hours (Table 4). However, these data are not worrisome because, in a more detailed analysis, it is observed that the statistical difference is not due to the increase of the frequency of damages in the animals supplemented with brown flaxseed, but to the reduction of the basal damages of the animals controlled. Moreover, it can be verified in the literature that negative control groups may present a higher frequency of micronuclei than that observed for these animals supplemented with brown flaxseed. According to Mauro et al. ${ }^{4}$ animals from the negative control group in a similar study and from the same colony of animals recorded the baseline frequency of $8.72 \pm 1.11$ in $\mathrm{T} 1$ and of $5.54 \pm 0.73$ in $\mathrm{T} 2$ in mice. The same can be seen for Limeiras et al. ${ }^{33}$ reporting the baseline frequency of $15.28 \pm$ 1.04 in Swiss mice. It is further emphasized that the experiments reported here were conducted under the same conditions as the present research, and the animals are the same origin.

It should be emphasized that the supplementation with brown flaxseed, independently of the protocol used, has a chemopreventive action; except for the Pos-treatment and Simultaneous protocol in the 72 hour evaluation. In the other protocols and times of analysis the percentages of damage reduction ranged from 58.63 to $91.88 \%$ (Table 4).

The data of the comet and the micronucleus demonstrate complementary antigenotoxic / chemopreventive actions and are corroborated in the literature that already indicate anticarcinogenic action 25,27, antioxidant ${ }^{25,26}$ and anti-inflammatory ${ }^{26}$ for brown flaxseed. In addition, the literature mentions that dietary fiber has anticarcinogenic capacity that can increase intestinal transit facilitating the excretion of toxic products, improving the intestinal microbiota, inhibiting the chronic inflammatory process and the migration of cancerous cells in the colon ${ }^{38}$, as well as the capacity of adsorbers of mutagenic and / or carcinogenic agents of the enteric metabolic process 24,28 .

From these mechanisms of action it can be assumed that flaxseed can act by two mechanisms of antimutagenesis: the desmutagenesis and the bioantimutagenesis. In demutagenesis the toxic compound is inactivated by the chemopreventive functional food or its constituents, for example, in the extracellular medium. In the bioantimutagenesis the chemopreventive functional food and / or its constituents are able to modulate the repair enzymes and thus facilitate the correction of lesions in the DNA, reducing the chance of tumor development ${ }^{39}$.

Regarding the demutagenic and bioantimutagenic activities mentioned before, both can be identified for each protocol. The Pre-treatment protocol may indicate activity by both demutagenesis and bioantimutagenesis ${ }^{32}$. Previous DNA exposure to the flaxseed diet could induce cell enzymes to repair the damage caused by $\mathrm{DMH}$, for example, indicating bioantimutagenesis activity. However, the metabolites of DMH could be inactivated in the extracellular space or intracellularly by the components of the flaxseed and a process would then occur by demutagenesis. In the Simultaneous Treatment, the two events could occur at the same time ${ }^{4,13,15,23}$. Part of the flaxseed could adsorb the DMH still in the intestinal lumen or in the intracellular medium and, in this way, act by demutagenesis, as well as could modulate the repair system. On the other hand, the Posttreatment protocol would exclusively indicate the modulation of the cellular enzymes 
4,13,15,23, being indicative of bioantimutagenesis and, finally, the Pre+continuous protocol would add up the two activities ${ }^{4,13,15}$.

Table 4. Total frequency, mean values \pm standard error of the mean and percent harm reduction for genotoxicity and antigenotoxicity tests in the peripheral blood micronucleus assay of male Swiss mice fed commercial or commercial feed supplemented with $10 \%$ of flaxseed.

\begin{tabular}{|c|c|c|c|c|c|c|c|c|c|}
\hline \multirow{3}{*}{$\begin{array}{l}\text { Experimental } \\
\text { Groups }\end{array}$} & \multicolumn{6}{|c|}{ Frequency of micronucleus } & \multirow{2}{*}{\multicolumn{3}{|c|}{$\% \mathrm{RD}$}} \\
\hline & \multicolumn{3}{|c|}{ Absolute Values } & \multicolumn{3}{|c|}{ Medium values } & & & \\
\hline & $\begin{array}{l}\mathbf{T} \\
\mathbf{1}\end{array}$ & $\mathbf{T 2}$ & T3 & T1 & $\mathbf{T 2}$ & T3 & T1 & $\mathbf{T} 2$ & T3 \\
\hline Control & 8 & 5 & 5 & $1,14 \pm 1,07^{\mathrm{a}}$ & $0,71 \pm 0,76^{\mathrm{a}}$ & $0,71 \pm 0,76^{\mathrm{a}}$ & - & - & - \\
\hline DMH & $\begin{array}{l}27 \\
9\end{array}$ & 138 & 94 & $39,96 \pm 3,02^{\mathrm{e}}$ & $19,71 \pm 2,29^{\mathrm{d}}$ & $13,43 \pm 1,90^{\mathrm{c}}$ & - & - & - \\
\hline \multicolumn{10}{|l|}{ Genotoxicity } \\
\hline Flaxseed & 25 & 24 & 29 & $3,57 \pm 0,79^{\mathrm{a}, \mathrm{b}}$ & $3,43 \pm 1,27^{b}$ & $4,14 \pm 1,34^{\mathrm{b}}$ & - & - & - \\
\hline \multicolumn{10}{|l|}{ Antigenotoxicity } \\
\hline Pre-treatment & 44 & 27 & 21 & $6,29 \pm 1,38^{\mathrm{b}, \mathrm{c}}$ & $3,86 \pm 1,07^{b}$ & $3,00 \pm 1,15^{\mathrm{a}, \mathrm{b}}$ & 86,73 & 83,42 & 82,00 \\
\hline Simultaneous & 91 & 60 & 84 & $13,00 \pm 2,16^{\mathrm{d}}$ & $8,57 \pm 2,00^{c}$ & $12,00 \pm 2,08^{\mathrm{c}}$ & 69,45 & 58,63 & 11,24 \\
\hline Post-treatment & 48 & 33 & 24 & $6,86 \pm 1,34^{\mathrm{c}}$ & $4,71 \pm 1,11^{b}$ & $3,43 \pm 1,27^{b}$ & 85,26 & 78,95 & 78,61 \\
\hline Pre+continuous & 30 & 21 & 19 & $4,29 \pm 1,11^{\mathrm{b}, \mathrm{c}}$ & $3,00 \pm 0,82^{\mathrm{a}, \mathrm{b}}$ & $2,71 \pm 1,25^{\mathrm{a}, \mathrm{b}}$ & 91,88 & 87,95 & 84,28 \\
\hline
\end{tabular}

Legend: \% RD - Percent reduction of DNA damage. T1, T2 and T3 - blood samples taken after 24, 48 and 72 hours of the last application of DMH or EDTA. Control - EDTA $0.1 \mathrm{~mL} / 10 \mathrm{~g}$, b.w. (body weight); DMH-1,2-Dimethylhydrazine, 20mg / kg, b.w. during 2 weeks (positive control); Flaxseed - Linum usitatissimum - 10\% c.f. (commercial feed) for 4 weeks +72 hours; Pretreatment - Flaxseed $10 \%$ c.f. during the first 2 weeks + DMH 20mg / kg b.w. for 2 weeks; Simultaneous Treatment - Flaxseed $10 \%$ c.f. + DMH 20mg / kg, b.w.for 2 weeks; Post-Treatment - DMH 20mg / kg, b.w. for 2 weeks + flaxseed $10 \%$ c.f. for 72 hours thereafter; Pre+continuous treatment - flaxseed $10 \%$ c.f. for 4 weeks +72 hours + DMH $20 \mathrm{mg} / \mathrm{kg}$, b.w. for 2 weeks. Different letters indicate statistically significant differences ( $\mathrm{p}<0.05$; ANOVA / Tukey).

The evaluation of the differential count is presented in Table 5. It is emphasized that in the analysis of 24 hours the percentage of lymphocytes is within the reference values only in the group that received only brown flaxseed and the group that received only DMH. All experimental groups have basophil values above the reference values and are significantly different from each other. In the 48 hour analysis, only DMH, Pretreatment, Simultaneous and Post-treatment groups presented significant differences. The Pre+continuous group were highlighted by a significant reduction in the number of neutrophils. In relation to basophils, the highest value is of the DMH group (3.57 \pm 1.98), being the only group that differs statistically from the others. As for neutrophils, the highest and lowest values, which differ significantly, were $37.71 \pm 4.88$ and 27.42 \pm 9.84 for the Post-treatment and Control groups, respectively. The DMH, Brown flaxseed, Pre-treatment groups presented higher values than the reference ones for the eosinophils, with significant difference between the groups. In relation to basophils there is an increase in DMH, Pre-treatment and Simultaneous groups. In addition, a picture of monocytosis in the three evaluated times was evidenced.

Even though this antigenotoxic activity is observed, many cells with genomic lesions still remain in the organism. Another possibility of organic protection would be the capture of these cells and, later, destruction. It is known that the hematopoietic system, as well as the cells of the lymphoid ( $\mathrm{T}$ and $\mathrm{B}$ lymphocytes) and myeloid cells (erythrocytes, platelets, macrophages, neutrophils, eosinophils and basophils) that derive from it, perform specific functions being capable of this activity ${ }^{40}$. It quotes for example, macrophage, which, when activated, can secretes cytokines with tumoricidal activity, such as TNF- $\alpha$ that induces death by apoptosis ${ }^{41}$, and $\mathrm{T}$ lymphocytes that protect against viruses and intracellular microorganisms, besides participating in the destruction of tumor cells ${ }^{40}$ 
Table 5. Mean values \pm standard error of the mean differential count of peripheral blood cells of male Swiss mice fed either commercial or commercial ration supplemented with $10 \%$ flaxseed.

\begin{tabular}{|c|c|c|c|c|c|c|c|c|}
\hline \multirow[t]{2}{*}{ Parameters } & \multirow[t]{2}{*}{ Val. Ref. } & \multicolumn{7}{|c|}{ Experimental Groups } \\
\hline & & Control & DMH & Flaxseed & Pre-treatment & Sim & Post & Pre+continuous \\
\hline \multicolumn{9}{|l|}{24 hours } \\
\hline Lymphocyte & $55-95 \%$ & $51.00 \pm 3.05^{\mathrm{a}}$ & $59.42 \pm 4.03^{\mathrm{b}}$ & $65.71 \pm 3.77^{b}$ & $52.14 \pm 3.57^{\mathrm{a}}$ & $51.14 \pm 2.96^{\mathrm{a}}$ & $51.71 \pm 2.87^{\mathrm{a}}$ & $47.71 \pm 5.61^{\mathrm{a}}$ \\
\hline Neutrophil & $10-40 \%$ & $33.42 \pm 3.86^{\mathrm{a}}$ & $43.28 \pm 2.13^{c}$ & $31.28 \pm 3.30^{\mathrm{a} . \mathrm{b}}$ & $33.85 \pm 2.47^{\mathrm{a}}$ & $30.00 \pm 2.94^{\mathrm{a} . \mathrm{b}}$ & $29.14 \pm 4.59^{a . b}$ & $26.14 \pm 3.62^{\mathrm{b}}$ \\
\hline Monocyte & $0.1-3.5 \%$ & $3.28 \pm 1.11^{\mathrm{a}}$ & $5.71 \pm 1.38^{\mathrm{a}}$ & $1.85 \pm 1.77^{\mathrm{a}}$ & $11.42 \pm 1.71^{\mathrm{b}}$ & $12.85 \pm 2.19^{b}$ & $14.57 \pm 3.78^{\mathrm{b}}$ & $19.71 \pm 4.27^{\mathrm{c}}$ \\
\hline Eosinophil & $0-0.4 \%$ & $0.00 \pm 0.00^{\mathrm{a}}$ & $0.00 \pm 0.00^{\mathrm{a}}$ & $0.28 \pm 0.488^{a}$ & $0.42 \pm 0.53^{\mathrm{a}}$ & $0.00 \pm 0.00^{\mathrm{a}}$ & $0.00 \pm 0.00^{\mathrm{a}}$ & $0.00 \pm 0.00^{\mathrm{a}}$ \\
\hline Basophile & $0-0.3 \%$ & $2.42 \pm 1.71^{\mathrm{a}}$ & $1.42 \pm 1.98^{\mathrm{a}}$ & $0.85 \pm 0.89^{\mathrm{a}}$ & $2.14 \pm 1.06^{\mathrm{a} . \mathrm{b}}$ & $6.00 \pm 1.52^{b . c}$ & $4.57 \pm 1.71^{\mathrm{b} . c}$ & $6.42 \pm 4.35^{\mathrm{c}}$ \\
\hline \multicolumn{9}{|l|}{48 hours } \\
\hline Lymphocyte & $55-95 \%$ & $55.00 \pm 7.68^{\mathrm{a}}$ & $39.00 \pm 7.21^{b}$ & $53.42 \pm 4.27^{\mathrm{a} . \mathrm{b}}$ & $48.42 \pm 3.95^{a . b}$ & $44.42 \pm 5.59^{\text {b.c }}$ & $39.14 \pm 4.77^{c}$ & $63.71 \pm 3.63^{d}$ \\
\hline Neutrophil & $10-40 \%$ & $28.28 \pm 6.26^{\mathrm{a}}$ & $37.57 \pm 6.26^{\mathrm{b}}$ & $23.00 \pm 2.76^{\mathrm{a}}$ & $29.28 \pm 5.37^{\mathrm{a}}$ & $29.85 \pm 3.53^{\mathrm{a}}$ & $37.85 \pm 4.01^{\mathrm{b}}$ & $10.28 \pm 1.97^{\mathrm{c}}$ \\
\hline Monocyte & $0.1-3.5 \%$ & $16.28 \pm 5.28^{\mathrm{a}}$ & $19.85 \pm 4.45^{\mathrm{a} . \mathrm{b}}$ & $23.14 \pm 3.43^{\mathrm{b}}$ & $22.00 \pm 4.08^{\mathrm{a} . \mathrm{b}}$ & $25.28 \pm 3.20^{\mathrm{b}}$ & $23.00 \pm 2.00^{\mathrm{b}}$ & $26.00 \pm 3.416^{\mathrm{b}}$ \\
\hline Eosinophil & $0-0.4 \%$ & $0.00 \pm 0.00^{\mathrm{a}}$ & $0.00 \pm 0.00^{\mathrm{a}}$ & $0.00 \pm 0.00^{\mathrm{a}}$ & $0.00 \pm 0.00^{\mathrm{a}}$ & $0.00 \pm 0.00^{\mathrm{a}}$ & $0.00 \pm 0.00^{\mathrm{a}}$ & $0.00 \pm 0.00^{\mathrm{a}}$ \\
\hline Basophile & $0-0.3 \%$ & $0.42 \pm 1.13^{\mathrm{a}}$ & $3.57 \pm 1.98^{\mathrm{b}}$ & $0.42 \pm 0.78^{a}$ & $0.28 \pm 0.48^{a}$ & $0.42 \pm 0.53^{\mathrm{a}}$ & $0.00 \pm 0.00^{\mathrm{a}}$ & $0.00 \pm 0.00^{\mathrm{a}}$ \\
\hline \multicolumn{9}{|l|}{72 hours } \\
\hline Lymphocyte & $55-95 \%$ & $69.57 \pm 10.34^{\mathrm{a}}$ & $37.71 \pm 5.55^{\mathrm{b}}$ & $61.14 \pm 3.28^{\mathrm{a} . \mathrm{c}}$ & $63.57 \pm 3.64^{\mathrm{acc}}$ & $59.85 \pm 5.42^{\mathrm{c}}$ & $56.57 \pm 5.47^{\mathrm{c}}$ & $62.85 \pm 3.62^{\text {a.c }}$ \\
\hline Neutrophil & $10-40 \%$ & $27.42 \pm 9.84^{\mathrm{a}}$ & $32.57 \pm 2.87^{a . b}$ & $33.85 \pm 3.48^{\mathrm{a} . \mathrm{b}}$ & $33.71 \pm 3.77^{a . b}$ & $32.85 \pm 4.52^{\mathrm{a} . \mathrm{b}}$ & $37.71 \pm 4.88^{\mathrm{b}}$ & $26.57 \pm 3.69^{\mathrm{a}}$ \\
\hline Monocyte & $0.1-3.5 \%$ & $3.00 \pm 2.23^{\mathrm{a}}$ & $24.28 \pm 5.25^{\mathrm{d}}$ & $1.71 \pm 1.11^{\mathrm{a}}$ & $1.42 \pm 1.27^{\mathrm{a}}$ & $6.57 \pm 1.71^{b}$ & $5.71 \pm 1.60^{\mathrm{b}}$ & $10.57 \pm 1.81^{\mathrm{c}}$ \\
\hline Eosinophil & $0-0.4 \%$ & $0.00 \pm 0.00^{\mathrm{a}}$ & $3.00 \pm 1.75^{\mathrm{b}}$ & $3.14 \pm 1.34^{\mathrm{b}}$ & $0.85 \pm 0.89^{a}$ & $0.14 \pm 0.37^{\mathrm{a}}$ & $0.00 \pm 0.00^{\mathrm{a}}$ & $0.00 \pm 0.00^{\mathrm{a}}$ \\
\hline Basophile & $0-0.3 \%$ & $0.00 \pm 0.00^{\mathrm{a}}$ & $2.42 \pm 1.90^{\mathrm{b}}$ & $0.14 \pm 0.37^{\mathrm{a}}$ & $0.42 \pm 0.53^{\mathrm{a}}$ & $0.57 \pm 0.78^{a}$ & $0.00 \pm 0.00^{\mathrm{a}}$ & $0.00 \pm 0.00^{\mathrm{a}}$ \\
\hline
\end{tabular}

Legend: Ref. Values - Reference Values. T1, T2 and T3 - blood samples taken after 24, 48 and 72 hours of the last application of DMH or EDTA. Control - EDTA 0.1mL / 10 g. b.w. (body weight); DMH -1,2-Dimethylhydrazine, 20mg / kg, b.w. during 2 weeks (positive control); Flaxseed - Linum usitatissimum - 10\% c.f. (commercial feed) for 4 weeks +72 hours; Pretreatment - Flaxseed $10 \%$ c.f. during the first 2 weeks + DMH $20 \mathrm{mg} / \mathrm{kg}$ b.w. for 2 weeks; Simultaneous Treatment - Flaxseed $10 \%$ r.c + DMH $20 \mathrm{mg} / \mathrm{kg}$, b.w. for 2 weeks; Post-Treatment - DMH 20mg / kg, b.w. for 2 weeks + flaxseed $10 \%$ c.f. for 72 hours thereafter; Pre+continuous treatment - flaxseed $10 \%$ c.f. for 4 weeks +72 hours + DMH $20 \mathrm{mg} / \mathrm{kg}$, b.w. for 2 weeks. Different letters indicate statistically significant differences ( $\mathrm{p}<0.05$; ANOVA / Tukey). 


\section{CONCLUSIONS}

Forward these considerations, it is verified that the supplementation of brown flaxseed was efficient in promoting increase of cell types related to the removal of cells with genomic / genetic instability of the organism. This fact corroborates the hematological evaluation, which indicated a significant increase in the number of monocytes and lymphocytes in the groups that received the diet with brown flaxseed. Thus, there was a change in the immune response to the proliferation of cells with DNA lesions caused by DMH treatment. Treatment with DMH and flaxseed supplementation would be events that favor the increase of phagocytosis and the elimination of cells started for the process of genetic instability and, consequently, for cancer.

Given the reports presented and discussed, it is considered that the supplementation with brown flaxseed is safe and reduces the frequency of lesions in the DNA that can lead to the development of tumors. Therefore, if these same events in humans are proven, flaxseed will have reinforced its indication as a functional chemo-preventive food for use in cancer prevention.

\section{REFERENCES}

1. World Health Organization (WHO). Fact Sheet No. 297: Cancer (2015). Available from: http://www.who.int/mediacentre/factsheets/fs297/en/.

2. World Health Organization (WHO). Cancer Fact Sheet (2017). Available from: http:// www.who.int/mediacentre/factsheets/fs297/en/.

3. Instituto Nacional do Câncer (INCA) (2017) Estimativa 2018: Incidência de Câncer no Brasil. Instituto Nacional de Câncer Jose Alencar Gomes da Silva. Coordenação de Prevenção e Vigilância. Available from: http://www.inca.gov.br/estimativa/2018/.

4. Mauro MO, Monreal MT, Silva MT, Pesarini JR, Mantovani MS, Ribeiro LR, et al. Evaluation of the antimutagenic and anticarcinogenic effects of inulin in vivo. Genet Mol Res. 2013; 12(3): 2281-2293. 10.4238/2013.July.8.9.

5. Blue Ribbon Panel (BRP). Cancer Moonshot Blue Ribbon Panel Report 2016. Available from: https://www.cancer.gov/research/key-initiatives/moonshot-cancer-initiative/blueribbon-panel.

6. Kajla P, Sharma A, Sood DR. Flaxseed-a potential functional food source. J Food Sci Technol. 2015; 52(4): 1857-1871.

7. Rodriguez-Leyva D, Weighell W, Edel AL, LaVallee R, Dibrov E, Pinneker R, et al. Potent antihypertensive action of dietary flaxseed in hypertensive patients. Hypertens. 2013; 62(6): 1081-9.

8. Yari Z, Rahimlou M, Eslamparast T, Ebrahimi-Daryani N, Poustchi H, Hekmatdoost A. Flaxseed supplementation in non-alcoholic fatty liver disease: a randomized, open, controlled and controlled pilot study. Int J Food Sci Nutr. 2016; 67(4): 461-9.

9. Sok D, Cui HS, Kim MR. Isolation and bioactivities of furfuran type lignin compounds from edible plants. Recent Pat Food Nutr Agric. 2009; 1(1): 87-95.

10. Lemay-Nedjelski L, Mason-Ennis JK, Taibi, Comelli EM, Thompson LU. Omega-3 Polyunsaturated Fatty Acids Time-Dependently Reduce Cell Viability and Oncogenic MicroRNA-21 Expression in Estrogen Receptor-Positive Breast Cancer Cells (MCF-7). Int J Mol Sci. 2018; 19(1): 244.

11. Edel AL, Rodriguez-Leyva D, Maddaford TG, Caligiuri SP, Austria JA, Weighell W, et al. Dietary flaxseed independently lowers circulating cholesterol and lowers it beyond the effects of cholesterol-lowering medications alone in patients with peripheral artery disease. J Nutr. 2015; 145(4): 749-757.

12. Ricklefs-Johnson K, Johnston CS, Sweazea KL. Ground flaxseed increased nitric oxide levels in adults with type 2 diabetes: a randomized comparative effectiveness study of supplemental flaxseed and psyllium fiber. Obesity Medicine. 2017; 5:16-24.

13. Ishii PL, Prado CK, Mauro MDeO, Carreira CM, Mantovani MS, Ribeiro LR, et al. Evaluation of Agaricus blazei in vivo for antigenotoxic, anticarcinogenic, phagocytic and immunomodulatory activities. Regul Toxicol Pharmacol. 2011; 59(3): 412-422. 
14. Cantero WB, Takahachi NA, Mauro MO, Pesarini JR, Rabacow AP, Antoniolli AC, et al. Genomic lesions and colorectal carcinogenesis: the effects of protein-calorie restriction and inulin supplementation on deficiency statuses. Genet Mol Res. 2015; 14(1): 2422-2435.

15. Navarro SD, Mauro MO, Pesarini JR, Ogo FM, Oliveira RJ. Resistant starch: a functional food that prevents DNA damage and chemical carcinogenesis. Genet Mol Res. 2015; 14(1): 1679-1691.

16. Oliveira RJ, Navarro SD, De Lima DP, Meza A, Pesarini JR, da Silva Gomes R, et al. A novel cytosporone 3-Heptyl-4, 6-dihydroxy-3 H-isobenzofuran-1-one: synthesis; toxicological, apoptotic and immunomodulatory properties; and potentiation of mutagenic damage. BMC Cancer. 2015; 15: 561.

17. Kobayashi H, Sugiyama C, Morikawa Y, Hayashi M, Sofuny T. A comparison between manual microscopic analysis and computerized image analysis in the single cell gel electrophoresis assay. MMS Commun. 1995; 3: 103-115.

18. Oliveira RJ, Matuo R, Silva AF, Matiazi HJ, Mantovani MS, Ribeiro LR. Protective effect of $\beta$-glucan extracted from Saccharomyces cerevisiae against SNS damage and cytotoxicity in wild-type (k1) and repair-deficient (xrs5) CHO cells. Toxicol in vitro. 2007; 21(1): 4152.

19. Hayashi M, Morita T, Kodama Y, Sofuni T, Ishidate M Jr. The micronucleus assay with mouse peripheral blood reticulocytes using acridine orange-coated slides. Mutat Res. 1990; 245(4): 245-249.

20. Oliveira RJ, Salles MJ, Da Silva AF, Kanno TY, Lourenço AC, Freiria GA, et al. Effects of the polysaccharide b-glucan on clastogenicity and teratogenicity caused by acute exposure to cyclophosphamide in mice. Regul Toxicol Pharmacol. 2009a; 53(3): 164-173.

21. Oliveira RJ, Baise E, Mauro MDE O, Pesarini JR, Matuo R, Silva AF, et al. Evaluation of chemopreventive activity of glutamine by the comet and the micronucleus assay in mice's peripheral blood. Environ Toxicol Pharmacol. 2009b; 28(1): 120-124.

22. Figueiredo RC. 2006. Efeitos da grandisina sobre o efeito hematopoiético, em camundongos. Dissertação, Universidade de São Paulo.

23. Pesarini JR, Zaninetti PT, Mauro MO, Carreira CM, Dichi JB, Ribeiro LR, et al. Antimutagenic and anticarcinogenic effects of wheat bran in vivo. Genet Mol Res. 2013; 12(2): 1646-1659.

24. Morris DH. Flax - a health and nutrition primer. Flax Council, Canada, 2007.

25. Ezzat SM, Shouman SA, Elkhoely A, Attia YM, Elsesy MS, El Senousy AS, et al. Anticancer potentiality of lignan rich fraction of six Flaxseed cultivars. Scientific Reports. 2018; 8: 544.

26. Xie N, Zhang W, Li J, Liang H, Zhou H, Duan W, et al. Alpha-Linolenic acid intake attenuates myocardial ischemia/reperfusion injury through anti-inflammatory and antioxidative stress effects in diabetic but not normal rats. Arch Med Res. 2011; 42(3): 171181.

27. Truan JS, Chen JM, Thompson LU. Flaxseed oil reduces the growth of human breast tumors (MCF-7) at high levels of circulating estrogen. Mol Nutr Food Res. 2010; 54(10): 1414-21.

28. Beecher GR. Phytonutrients role in metabolism: effects on resistance to degenerative processes. Nutr Rev. 1999; 57: 3-6.

29. Newell LE, Heddle JA. The potent colon carcinogen, 1,2-dimethilhydrazine induces mutations primarily in the colon. Mut Res. 2004; 564(1): 1-7.

30. Tanaka T. Colorectal carcinogenesis: review of human and experimental animal studies. $J$ Carcinog. 2009; 8: 5.

31. Oliveira RJ, Salles MJS, da Silva AF, Kanno TYN, Lourenço AC, Leite Vda S, et al. In vivo evaluation of the antimutagenic and antigenotoxic effects of $\beta$-glucan extracted from Saccharomyces cerevisiae in acute treatment with multiple doses. Genet Mol Biol. 2013; 36(3): 413-424.

32. Limeiras SMA, Ogo FM, Genez LAL, Carreira CM, Oliveira EJ, Pessatto LR, et al. Prevention of DNA damage and anticarcinogenic activity of Activia ${ }^{\circledR}$ in a preclinical model. Genet Mol Res. 2017;16(1).

33. Hernández-Salazar M, Guevara-González RG, Cruz-Hernández A, Guevara-Olvera L, Bello-Pérez LA, Castaño-Tostado E, et al. Flaxseed (Linum usitatissimum L.) and its total non-digestible fraction influence the expression of genes involved in azoxymethaneinduced colon cancer in rats. Plant Foods Hum Nutr. 2013; 68(3): 259-67. 
34. Gomides AF, Gonçalves RV, de Paula SO, Ferreira CL, Comastri DS, Peluzio Mdo C. Defatted flaxseed meal prevents the appearance of aberrant crypt foci in the colon of mice increasing the gene expression of p53. Nutr Hosp. 2015; 31(4): 1675-81.

35. Geigl JB, Obenauf AC, Schwarzbraun T, Speicher MR. Defining 'chromosomal instability'. Trends Genet. 2008; 24(2): 64-69.

36. Choudhary G, Hansen H. Human health perspective on environmental exposure to hydrazines: a review. Chemosphere. 1998; 37(5): 801-43.

37. Richards TC. Early changes in the dymanics of cryptcell populations in mouse colon following administration of 1,2-dimethylhydrazine. Cancer Res. 1977; 37(6): 1680-1685.

38. Zeng H, Lazarova DL, Bordonaro M. Mechanisms linking dietary fiber, gut microbiota and colon câncer prevention. World J Gastrointest Oncol. 2014; 6(2): 41-51.

39. Kada T, Shimoi K. Desmutagens and bio-antimutagens - their modes of action. BioEssays. 1987; 7(3): 113-116.

40. Vanputte CL, Regan JL, Russo AF. Anatomia e fisiologia de seeley. Porto Alegre, AMGH, 2016.

41. Voltarelli JC, Pasquini R, Ortega ETT. Transplante de células-tronco hematopoiéticas. São Paulo, Atheneu, 2009. 